\title{
Register rerum ad Vol. 1
}

\section{Bearbeitet von W.}

Äbrahamsen, Harald †, 223

Arteriographische Untersuchungen an der tuberkulösen Niere, 153

Atypische Epithelverbände der weib-lichen Harnröhrenmündung, 71

Ausscheidungs-Urographie, Extravasation bei, 191

Bladder, Malakoplakia, 5

-, Papillomas, 315

-, Paralysis in Herpes Zoster, 139

-, the Sensory Innervation, 108

-, Treatment of Cancer, 25

Blase, v. Bladder

Blasenkrebs, die Behandlung des, 25

Blasenlähmung bei Herpes zoster, 139

Blasen-Scheidenfistel, v. Vesicovaginal

Fistulae Blasenphysiologie, Prüfung mit Cysto-

metrie und Sphincterometrie, 427

Cancer de la vessie, le traitement, 25 -, of the Urinary Bladder, Treatement

of, 25 Carcinom, Differentialdiagnose bei aty-

pischen Epithelverbänden der weib-

lichen Harnröhrenmündung, 71 Cavernosogramm, Gavernosographie,

120 Cobaye, v. Meerschweinchen Courants à haute frequence, v. Hoch-

frequente Ströme Cystometrie und Sphincterometrie, 427

Duodenalfistel nach Nephrektomie, 15

Elektrochirurgie, transurethrale, 293 Electro-Surgery, transurethral, 293 Entéroanastomose

urétérale, 256 Enuresis, v. Inkontinenz Epitheliums atypiques, v. atypische

Epithelverbände Excretory Urography, v. Urographie

intraveineuse Extravasation in Excretory Urography.

191 Fistules urétéro-vaginales, le traitement

et ses résultats, 332

$\mathrm{m}$ ad Vol. 1

Baumann, Basel

Fistules vésico-vaginales (petites), traitement opératoire, 66

Guinea Pigs, v. Meerschweinchen

Haemangiom der Harnblase, 43 Harnblase, v. Blase, Bladder Harnleiter, v. Ureter

Harnleiterdarmanastomose, 256 Harnsteine, v. Urinary Calculus Herpes Zoster, Paralysis of the

Bladder,

139 High Frequency Currents, v. Hochfre-

quente Ströme Hochfrequente Ströme für transurethrale

Operationen, 293 Hydrazide de $\Gamma$ acide isonicotinique v. 
Isonikotinsäure-hydrazid Hypertrophie prostatique et Гinconti-

nence urinaire, nouvelles possibilités

pour le traitement médicamenteux,

440

Inkontinenz (Harn-), neue medikamen-töse Behandlungsmöglichkeiten, 440

Isonikotinsäure-hydrazid, Behandlung der Urogenítaltuberkulose, 63

Karzinom, Krebs, v. Cancer, Carcinom Kidney, Arteriographic Studies by

Tuberculosis, 153 -, Malakoplakia, 5

-, Partial Resection by Tuberculosis, 359 Lithiasis urinaire, v. Urinary Calculus Lowsley,

Oswald Swinney $\uparrow, 79$

Malacoplasie, v. Malakoplakia Malakoplakia Involving the Bladder and

One Kidney and Ureter, 5 Manometrie der Harnblase, 427

Meerschweinchen, apathogeneTuberkel-bazillen nach Behandlung mit Isonikotinsäure-hydrazid,

63

Néphrectomie droite et fistule duodénale,

15 -, partielle, 243

- - pour tuberculose, 199, 359 Nerfs spinaux, v. Spinal Nerve

450

Register rerum

$1 / 1955$

Niere, v. Kidney Nierenteilresektion, v. Néphrectomie

partielle, Partial Nephrectomy Nierentuberkulose, v. Tuberculose uro-

génitale, Urogenital Tuberculosis

Papillomas of the Urinary Bladder, 315

Partial Nephrectomy, 243

-, in the Treatment of Tuberculosis, 199

Partial Resection of the Kidney and of the Ureter by Urogenital Tuberculosis, 359

Penis, a Case of Double, 188

Phosphore radioactif dans urologie, 344

Prostata, Partial Resection by Tuberculosis, 359

Prostatahypertrophie und Harninkonti-nenz, neue medikamentöse Behand-lungsmöglichkeiten, 440

Prostatic Hypertrophy and Enuresis, New Ways in the Medical Treatment, 440

Prostatovesiculitis, Chronic, and Affections of the Spinal Nerve Roots, 171

Pyelonephritis, Diagnosis by Means of the Sternheimer-Malbin Urinary Sediment Stain, 225

Radioactive Phosphorus (Experimentally) in the Urology, 344

Radiological Investigations of Urogenital Tuberculosis, 396

Raveron, 440

Rayons-X, les risques 135

Rein, v. Kidney

Renogramm bei Tuberkulose, 153

Röntgenstrahlen, Gefährdung durch, 135

Sediment urinaire, v. Urinary Sediment Sphincterometrie und Cystometrie, 427 Spinal Nerve

Roots, Affections of the, 
and Chronic Prostatovesiculitis, 171 Sternheimer-Malbin Urinary Sediment Stain in the Diagnosis of Pyelonephritis, 225

Transurethrale Operationen mit hoch-

frequenten Strömen, 293 Transvagínal Surgery of the Pelvic

Ureter, 267

Tuberculose urogénitale, examens arté-

riographiques sur le rein tuberculeux,

153 -, le traitement. La resection partielle

du rein et de Гuretère, 359 -, Гexamen radiographique, 396 -, néphrectomie partielle, 199 -, un

cas traité à $\Gamma$ hydrazide de l'acide

isonicotinique à bacilles tuberculeux

apathogènes pour le cobaye, 63 Tuberkelbazillen, für Meerschweinchen

apathogene, 63 Tuberkulose der Nieren, arteriogra-

phische Untersuchungen, 153 -, des Urogenitaltraktes, v. Tuberculose

urogénitale, Urogenital Tuberculosis

Uretère pelvien, Гabord vaginal, 267 Ureter, Malakoplakia, 5 -, Partial Resection by

Tuberculosis, 359 -, (Pelvic), Transvaginal Surgery, 267 Ureteric Stenoses, a Method for the

Treatement, 47 Uretero-Cysto-Neostomie, 332 Uretero-Intestinal Transplantation, 256 Uretero-

Vaginal Fistulae, the Treatement and its Results, 332 Urethra, atypische Epithelverbände der

weiblichen Harnröhrenmündung, 71 Urinary Calculus, a General Survey of

the Aetiology, 210 -, Sediment, Stain of Sternheimer-Malbin, 225 Urogenital Tuberculosis,

Arteriographic Studies on the Tuberculous Kidney, 153 -, an Isonicotinic-Acid-Hydrazide

Treated Case with Bacilli Non-Pathoge-netic to Guinea Pigs, 63 -, Partial Nephrectomy, 199 -,

Radiological Investigations, 396 -, the Selective Principle in the Treatment. Partial Resection of the Kidney and of the Ureter, 359. Urographies intraveineuses, les accidents

au cours des, 81 -, $\Gamma$ extravasation, 191

V. Varicocele, idiopathische, 142 Vesicovaginal Fistulae (small), Operative Treatement, 66

Vessie, v. Blase, Bladder Voelcker, Fritz $\dagger, 287$

X-Ray Hazards, 135 